SAD / JSR

Sosyoloji Araştırmaları Dergisi / Journal of Sociological Research

Cilt / Volume 22 Sayı / Number 1 (Nisan / April 2019) : (122-156)
Araştırma Makelesi / Research Article

Geliş Tarihi / Submited: 01.12.2017

Kabul Tarihi / Accepted: 02.01.2018

\title{
TÜRKIYYE'DE ÇERKES DİASPORASI: KİMLİK İNŞASI VE REFERANSLARI
}

\section{Bahar Ayça OKÇUOĞLU ${ }^{1}$}

\section{ÖZ}

Diasporalar kültürel öğeleri, dernekleri, aktiviteleri, politik alandaki etkileri ve gelecekteki rolleri açısından, bulundukları ülkeler için önem arz etmektedir. Türkiye'deki Çerkes diasporası da, aynı zamanda Çerkeslerin en büyük diasporik nüfus olduğu ülke olması bakımından, çeşitli özellikleri ele alınarak incelenmektedir. Bu çalışmada, Türkiye' deki diasporaların kimlik oluşum, dönüşüm ve değişim süreçlerine bir örnek olarak Çerkes diasporası incelenmiştir. Türkiye'deki Çerkeslerin varlığı, kurulan dernekler ve kapsamları, verilen referansların bağlamlarını kaybetmemeleri açısından ele alınmıştır. Çerkeslerin kendilerini ifade ediş süreçlerinde Kürt halkına ne tür referanslar verdiği, bu referansların diasporik bir topluluğun kendini tanımlaması açısından ne anlam ifade ettiği analiz edilmiştir. Bu analizler, Türkiye'nin çeşitli illerinde yapılan görüşmelerden elde edilmiş ve iki ana başlıkta incelenerek örnekler verilmiştir: “farklılıklar” ve "benzerlikler”. Böylece, Türkiye'de bir diaspora halkının varlığını ifade ediş biçimlerindeki farkl11ıklara bir örnek oluşturulmuştur.

Anahtar Kelimeler: Diasporik Kimlik, Çerkes, Çerkes Diasporası, Kürt Halkı 


\title{
CIRCASSIAN DIASPORA IN TURKEY: IDENTITY CONSTRUCTION AND ITS REFERENCES
}

\begin{abstract}
Diasporas matter with their cultural aspects, associations, activities, political effects and future roles in existing countries. Circassian diaspora have been examined in Turkey with its various features, in terms of being the biggest Circassian diasporic population in the world. This study had analyzed Circassian diaspora as an example of diasporas' identity formation, transformation and alteration processes in Turkey. To avoid the context loss, Circassians' existence, associations and their scope had analyzed. Circassian's references to Kurdish people in the self-expression process and the meaning of these references for identifying a diasporic community's itself had analyzed. These analyses had gathered from interviews which had conducted in various cities and had examined under two headings: "differences" and "similarities". Thus, an example of a diasporic community's various self-expression forms in Turkey had drawn.
\end{abstract}

Key Words: Diasporic Identity, Circassian, Circassian Diaspora, Kurdish People 


\section{GİRIŞ}

Günümüz Türkiye'sinde diasporalar, kültürel öğeleri, dernekleri, politik alandaki etkileri ve gelecekteki rolleri açısından uzun zamandır akademik çalışmaların konusu olmuştur. Buna bir örnek olarak Çerkes diasporası, gün geçtikçe artan akademik ilgiye sahip olmakla birlikte, nispeten yeni saha ve sözlü tarih çalışmaları ile nitelikli olarak incelenmektedir. Bu çalışmada da, Türkiye'deki diasporaların kimlik oluşum, dönüşüm ve değişim süreçlerine bir örnek olarak Çerkes diasporası incelenmiş; Çerkeslerin bu süreçlerde Kürt halkına ne tür referanslar verdiği analiz edilmiştir. Derneklerin Çerkeslerin kültüre ve kimliğe dair ifadelerinde önemli bir yer kaplaması göz önünde bulundurularak, çalışmanın analizinde Çerkes dernek temsilcileri ile yapılan derinlemesine mülakatlar kullanılmıştır.2 Bu görüşmeler sırasında Kürt halkına ve hareketine yapılan farklı nitelikteki atıflar, Türkiye'de bir diaspora halkının varlığını ifade ediş biçimindeki farklılıkları görmek açısından fikir kaynağı olmuştur.

Çalışma, diasporik kimliğin tanımlanması ve ifade edilişi ile ilgili çeşitli sorulara cevap aramaktadır: Çerkesler kimliklerini tanımlama süreçlerinde hangi referanslara başvurmaktadırlar? Bu süreçlerde ifade edilen öğelerden biri olan Kürt halkı ve hareketi, bir diasporanın incelenmesi açısından ne ifade etmektedir? Kolektif kimliğin inşa edilme ve değişim süreçlerinin önemli bir parçası olarak, karşıt ve kötü özelliklerin “öteki” gruba atfedilmesi ve anlamlandırılması konusunda, Çerkesler özelinde Kürtlerin önemli bir referans olduğu varsayılmaktadır. Buna ek olarak, özellikle daha politik diasporik bilince sahip genç Çerkes kuşağının, Kürt hareketinin sosyal ve siyasal kazanımlarına vurguyla daha pozitif referanslar vereceği öngörülmektedir.

\footnotetext{
${ }^{2}$ Alıntı yapılan görüşmelere ait tüm isim bilgileri değiştirilerek kullanılmıştır.
} 
Çalışma verileri “Türkiye'deki Diasporalar: Kuzey-Batı Kafkasya Halkları Örneği” başlıklı TÜBİTAK projesinde3 yüz yüze yapılan görüşmeler sonucunda elde edilmiştir. Bu kapsamda çalışmada, diaspora ve diasporik kimliğin teorik çerçevesi Çerkesler özelinde tartışılmış; Çerkes diasporasının Türkiye' deki tarihi ve günümüzdeki varlığı, kurulan dernekler ve kapsamları, diasporik kimliğin örneklerini sunmak açısından ifade edilmiştir. Daha sonraki bölümde elde edilen veriler, Çerkeslerin kendilerini birey ve topluluk olarak ifade ediş biçimlerine örnek olarak sunulmuş ve analiz edilmiştir.

Türkiye coğrafyasında yaşayan Kafkas halklarını tanımlayan "Çerkes” kelimesi, Türkiye ve Rusya coğrafyasında kullanılan, halkların kendilerince kullanılmasından önce devletler tarafından verilmiş bir çatı isimdir. Türkiye'de ise Çerkeslerin toplumu, kültürü ve dili açıklamak için üstünde anlaşılmış ortak bir terminoloji bulunmamaktadır (Besleney, 2016: 28). Kullanılan dile göre de değişiklik gösteren coğrafi alanlara dayalı ayrım, genel olarak üç kısımda incelenmektedir.4 Türkiye'de kullanılan "Çerkes" ismi ve Rusya'da kullanılan "Kafkasyalı" ismi, genel olarak üç coğrafi kısmı da kapsayan, Kafkasya coğrafyasından göç etmiş veya bu coğrafyada yaşayan halkları içermektedir. "Çerkes" kelimesinin tanımlaması kimi zaman Kuzey Kafkasya kökenli Adığe dilinde konuşan gruplar üzerinden yapılmıştır5, kimi zaman ise, farklı Çerkes grupları örnek verilmiştir. Örneğin Besleney (2009: 75; Besleney, 2016: 29) üç farklı "Çerkes” terimi kavramsallaştırmasını ifade eder. Birincisi; Çerkes’in Türkiye'deki tüm Kuzey Kafkasya diaspora halkına ait bir çatı isim anlamındaki kullanımıdır. Türkiye medyasında ve bazı Kuzey Kafkasya örgütleri arasında kullanılmakta olan bir terimdir. İkincisi, Kuzeybatı Kafkasya halkı olan,

3 İlgili TÜBİTAK Projesi (Proje no: 113K833), 2014 yılında Doç. Dr. Ulaş Sunata afından yürütülmüştür. Her ne kadar verilerin toplanma süresinin üzerinden zaman geçmiş ve bu süreçte ulus ve ötesi boyutlarda pek çok sosyal ve siyasi gelişme yaşanmış olsa da, toplumsal tutumların yavaş değişim gösterdiği göz ardı edilmemelidir.

${ }^{4}$ Kuzey-batı Kafkasyalılar, Kuzey (Kuzey-merkez) Kafkasyalılar ve Dağıstanlılar/Kuzey-doğu Kafkasyalılar. Çalışmanın da örneklemi olan Kuzey-batı Kafkasyalılar, Adığeler, Ubıhlar, Abhazlar ve Abazalar'dan oluşmaktadır. Adığeler ise, kendi içerisinde Şapsı̆̆ Besleney, Abzeh, Bjeduğ, Çemguy, Natuhay, Hatukay, Mamheğ, Mahoş ve Kabardey boylarından oluşmaktadır (Papşu, 2006). Bugün ise bazı boylar yüzyıllar içerisinde göç, savaş gibi nedenlerle diğer boylara göre oldukça az nüfusa sahiptir.

${ }^{5}$ Bunlara örnek olarak Şapsığlar, Abzehler, Ubıhlar ve Kabardeyleri verilmesine rağmen, Abhaz, Çeçen, İnguş, Karaçay, Balkar ve Dağıstan toplulukları dâhil edilmez (Kaya, 2005). 
Türkiye'deki Adığe, Abhaz, Abaza ve Ubıhları kapsayan bir terim olarak kullanımıdır. Bu topluluklar birbirine etnik ve dilsel açıdan bağlı, ama Kuzeydoğu Kafkas halklarından dil temelli farkı olan halklardır. Bu ikinci kullanım, çalışmaya göre Kafkas Dernekleri Federasyonu (KAFFED) tarafından çoğunlukla kullanılan terimdir. Üçüncü anlamı; 18. ve 19. yüzyılda dünyada Adığelere verilen terimdir.6 Çalışmada kullanılan "Çerkes" kelimesi ise, Besleney’in tanımlamasında ikinci madde olarak açıkladığı, TÜBİTAK projesi kapsamında da görüşmelerin yapıldığı Kuzeybatı Kafkasyalıları kapsamaktadır.

1850’lerden itibaren Kafkasya'dan Osmanlı'ya gerçekleşmiş olan zorunlu göçler ile Çerkesler, Anadolu coğrafyasının nüfus ve toplum yapısının önemli değişimler geçirmesine sebep olmuşlardır. Diaspora için önem arz eden 21 Mayıs 1864 tarihi, o gün yaşanıldığı bilinen büyük göçün genel sürgün için belirlenmiş ortak tarihidir ve yeni kuşağın da hafızasında canlı bir şekilde yer tutmaktadır (Özgür, 2013: 576; Hacisalihoğlu, 2013: 15). 1850’lerden 1950’lere kadar çeşitli nedenlerle süren bu göç/sürgün hareketi, bir milyondan fazla olduğu tahmin edilen göçmen/mültecilerin çeşitli yerlere iskân edilmesi ile sonuçlanmıştır (Shenfield, 1999). Rumeli coğrafyasından başlayarak Karadeniz kıyı kesimi boyunca, çoğunlukla gemilerle sürgün ettirilen bu nüfus, “Çerkes hattı” olarak bilinen ve bugün de büyük bir Çerkes nüfusunun yaşadığ1 Anadolu topraklarına göç ettirilmiştir. Bu hat, Sinop-Samsun'dan başlayarak, sırasıyla Çorum, Tokat, Sivas, Kayseri (özellikle Uzunyayla bölgesi), Maraş, Adana ve Hatay’a kadar uzanmaktadır.7 Aynı zamanda, bugün Güney ve Doğu Marmara'da da pek çok Çerkes köyü bulunmaktadır. Çerkesler, o dönem Osmanlı Devleti'nin hâkimiyetinde bulunan Suriye, Ürdün, Mısır gibi bölgelere de sürgün edilmişlerdir. Çerkesler, Osmanlı Devleti bünyesindeki etnik grupların ve dini azınlıkların isyan edebileceği düşüncesiyle

6 Birinci anlamın kullanımının sorun, günümüzde Oset, Çeçen, Dağıstan ve Karaçay-Balkar halk ve liderlerinin bu tanımı reddetmesidir. İkinci anlamın kullanımındaki sorun ise, özellikle Düzce ve Sakarya'nın şehir ve köy bölgelerinde yaşayan Abhaz halkının Çerkes tanımını tarihte ve günlük yaşamda kabul etmemeleri, ve yerel Türk topluluğun Abhaz ve Adığe arasındaki farkı her zaman bilmesidir. Bu sebeple Abhazlar diğer Kafkas halklarından daha önce kopuşlar yaşamış ve kendi isimleri ile organizasyonlarını kurmuşlardır. 1992-1993'teki Abhazya-Gürcistan savaşı da bu oluşumlara etkendir (Besleney, 2009).

7 Çalışmanın verilerini oluşturan görüşmelerin büyük bir kısmı da, bu hat üzerindeki köy ve şehirlerde gerçekleştirilen derinlemesine mülakatlardan oluşmaktadır. Köylerdeki görüşmelerin yanı sıra, dernekler ve şehirlerdeki kanaat önderleri ile 27 görüşme gerçekleştirilmiş ve bu çalışma için analiz edilmiştir. Derneklerde yapılan görüşmelerin detayları için bkz. Ek 1. 
planlı bir iskân politikasına tabi tutulmuşlardır (Doğan, 2009). Sürgün edilen nüfusun büyüklügü ile ilgili çalışmalar ve tartışmalar devam ettiği gibi8, Türkiye nüfus sayım sisteminde etnik azınlık grubu bilgileri kaydedilmediği için, bugünkü Çerkes nüfusunun büyüklüğünden kesin olarak bahsetmek mümkün değildir: nüfusun 250 binden 7 milyona kadar değiştiğine dair farklı tahminler bulunmaktadır (Erciyes, 2014: 436; Kaya, 2005: 12).

Türkiye'nin ve dünyanın pek çok yerine dağılmış olan Çerkesler için “diaspora” tanımını kullanmak halen tartışmalıdır. Diasporanın tanımı, bir topluluğun hangi koşullarda diasporik bir grup olarak adlandırılabileceği, değişen göç sistemleri ve globalleşmiş dünya çerçevesinde halen tartış1lmaktadır. Safran’a göre (1991: 83-84) “klasik diasporalar”; kendilerinin veya “atalarının” gerçek “merkez”lerinden iki veya daha fazla yabancı bölgeye dağıtılmış olmaları, ana vatanlarına ilişkin devam ettirilen bir kolektif hafıza veya görüş paylaşmaları, yerleştirilen "misafir" ülkede tam olarak kabul edilmediklerini ve belki de hiçbir zaman kabul edilemeyeceklerini düşünüp ayrık/kopuk ve yabancı hissetmeleri, ana vatanlarını idealleştirmeleri ve bu sebeple ana vatanlarına geri dönülmesi gerektiğini düşünmeleri, ana vatanlarının güvenliği ve refahı için korunmasına ve değişimine çalışmaları gerektiğine inanmaları, ana vatan ile ilişkilerini devam ettirmeleri ve bu ilişkinin etnik bilinçlerinin ve dayanışmalarının tanımlanmasında önemli bir yol olduğu düşüncesi ile oluşurlar. Klasik diasporalara örnek olarak Yahudi diasporasını inceleyen Tölölyan da (1996) diasporaların, kimliklerinin önemli bir parçası olarak kolektif hafızaya sahip olduklarını, birbirleri ile ilişkilerini devam ettirmeye önem verdiklerini, ana vatan ile ilişkilerini devam ettirdiklerini ve bu bağı ana vatan mitleri ile ifade ettiklerini belirtmiştir. Vertovec (1997), kolektif hafızaya sahip olan diasporik topluluğun diasporik farkındalığının/bilincinin yüksek olduğunu, ana vatanları ile ortak

${ }^{8}$ Göç ettirilen nüfusla ilgili çalışmalar için bkz. Shenfield, S. D. (1999). The Circassians: A Forgotten Genocide. Mark Levene ve R. Penny (Eds.), The Massacre in History içinde (s. 149-162). New York: Berghahn; Richmond, W. (2013). The Circassian Genocide (Genocide, Political Violence, Human Rights). New Brunswick: Rutgers University Press.

SAD / JSR

Cilt / Volume 22 Sayı / Number 1 
bağlara sahip olduklarını, ve bu bağların ulus-aşırı iletişim yaratarak yaşanılan ülkeyi de bu iletişime dâhil ettiğini belirtir.

Clifford (1994), diasporanın tanımlanması için Safran'ın belirlediği özelliklerin tümüne sahip olma gerekliliği bulunmadığını belirtmiştir:

“Günümüzde diasporaların varlığı, Safran'ın sözünü ettiği gibi sadece ana vatana geri dönüş isteği veya bir vatana aidiyet ile açıklanamaz. Geri dönüş isteğinin ve aidiyet hissinin yanı sıra yurtsuzlaşma deneyiminin verdiği acı, adaptasyon sürecinde karşılaşılan sorunlar ve muhalif olmanın getirdiği ortak bilinç de diasporanın oluşumunda önemli etkiye sahiptir” (Clifford, 1994'den aktaran Kaya, 2011: 28).

Brubaker (2005: 5), değişen dünya perspektifiyle, bir grubun diaspora olarak tanımlanabilmesi için üç koşulun yeterli olduğunu ortaya koymuştur: dağılmış olması, ana vatan odaklı olması ve psikolojik sınırlarının korunması. Cohen (2008: 16) ise, Safran'ın koşullarına ek olarak her diasporanın her bir kritere sahip olma ve aynı seviyede kriterleri karşılama gibi bir zorunluluğu olmadığını ekleyerek, "ortak" özellikleri vurgulamıştır. Geleneksel ve modern diasporaların ayrımını yaparak, küreselleşmenin bağlantısıyla eski ve yeni diasporaları kapitalizm öncesi (Ermeni, Yahudi ve Çerkes diasporaları) ve kapitalizm sonrası (İrlandalı, Çinli, Hintli, Sih ve Türk diasporaları) olarak sınıflandırmıştır (Kaya, 2012). Safran'ın kullandığı ilk kritere, yaşanan travmatik ve ortak hafızayı güçlendiren, grubu bir arada tutan bir olayın eklenmesi gerektiğini belirtir. Aynı zamanda bir diğer kritere, ana yurdun yeniden yaratımının da eklenmesini gerektiğini söyler. Eklediği diğer dört özelliğin birincisi, bireylerin iş arama, kolonyal veya ticari sebeplerle dağılmış (ana vatandan ayrılmış) olabileceğidir. İkincisi, diasporik kimliği sürdürmenin pozitif yanlarının da olabileceği, bireysel ve topluluk olarak başarılı olunabileceğinin göz ardı edilmemesi gerektiğidir (bu kategoriye Babil'de yaşamış Yahudileri örnek verir). Üçüncüsü, kolektif kimliğin oluşumunun sadece yerleşilmiş olan bölge ile sınırlı kalmadığı, farklı ülkelerden aynı etnik kökene sahip 
insanlarla da bağlılık/dayanışma içerisinde olunabileceğidir (ortak dil, din, kültür ve hatta ortak kader inancı bu uluslararası bağı oluşturan etmenlerdendir). Dördüncüsü, bazı durumlarda diaspora teriminin ulus-aşırı bağlardan oluşan dayanışma duygusunu açıklamak için kullanılabileceğidir.

Bu bağlamda, yukarıda çerçevesi çizilen farklı diaspora kavramları ve tezleri göz önünde bulundurularak; diasporik grubun belirtilen her kriteri karşılama şartının olmadığı (Cohen, 2008), diasporanın varlığının sadece ana vatana geri dönüş isteği ile açıklanamayacağı (Clifford, 1994), diasporik kimliğin önemli bir parçası olarak kolektif hafizanın var olması gerektiği (Tölölyan, 1996; Vertovec, 1997) yaklaşımları vasıtasıyla, Türkiye'deki Çerkesler bir diaspora olarak adlandırılabilmektedir. Çerkesler ana vatan saydıkları Kafkasya'dan Rumeli, Anadolu ve Mezopotamya gibi farklı bölgelere dağıtıldıkları gibi; Ermeni ve Yahudi diasporaları gibi travmatik nedenlerle terk etmek zorunda kaldıkları ana vatanlarına ait olguyu güçlü bir biçimde kuşaktan kuşağa aktarmaktadırlar (Shami, 1995), ve “anavatanlarına pek çok bakımdan bağlı olarak geri dönüş özlemi taşıyarak azınlık olma bilinçlerini anavatanlarına referansla diri tutmaktadırlar" (Kaya, 2011: 149; Arslan, 2013: 62). Herhangi bir diasporanın hem kendi içinde hem de diğer diasporalar ile homojen olma zorunluluğu taşımaması çerçevesinden hareketle (Clifford, 1994), Çerkesler de Türkiye' de homojen bir grup olmaktan ziyade, farklı diaspora deneyimlerini birbirinden farklı şekillerde yaşamaktadırlar. Diasporik kimliğin oluşumda ayrımcılık, dışlanma, gidilen ülkeye uyum sağlama veya yeni değerleri kabul etme şeklinde deneyimlenebilen farklı biçimler (Vertovec, 1997), Çerkesler özelinde de görülebilmektedir. Kentsel ve kırsal alanda ortaya çıkan kültürel farklılıklar, yaş gruplarına ve cinsiyete göre farklı deneyimlenen Çerkeslik, Türklük/Türkiyelilik ve Çerkeslik arasında gidip gelen tanımlamalar, Çerkes toplumunun diaspora olma halini farklı şekillerde yaşadığını göstermektedir. Her ne kadar Çerkes topluluğu içerisinde "ana vatanlarını” Kafkasya olarak değil, Türkiye olarak tanımlayanlar, ana dilini bilmeyip öğrenme motivasyonuna sahip olmayanlar, diğer etnik gruplar ile 
yapılan evliliklere sıcak bakanlar, "dönüşçü”9 olmayanlar ("ana vatan” olan Kafkasya'ya geri dönüş planı olmayanlar) olsa da, Çerkes toplumunu (veya bir kesimini) diaspora olarak tanımlamamak (Wakizaka, 2012), yapılmış olan sosyal, kültürel ve siyasal çabalara haksızlık olacaktır.

\section{TÜRKIYYE'DE ÇERKES DİASPORASI: KIMMLİĞİN OLUŞUM VE DÖNÜŞÜM MEKANIZMALARI}

Kimliğin oluşumu, “ben kimim?” veya “biz kimiz?” sorularına yüklenen anlamlar ve atıflar doğrultusunda verilen yanıtlar ile ilerler. $\mathrm{Bu}$ anlamda, kimliğin kişisel-bireysel ve toplumsal iki boyutu olduğundan bahsetmek mümkündür. Kimlik, kültürle ilişkisi kopmaksızın kişinin, cemaatin veya toplumun kendini algılayışı ve bunu dışa vuruş biçimidir (Assmann, 2001). Sosyal bilimlerin tartışmalı alanı olarak kimlik, pek çok anlamlarda kullanılması ile birlikte çoklu, durağan/sabit olmayan, değişken ve parçalanmış yapısı ile var olmaktadır (Brubaker ve Cooper, 2000: 8). Kimlik ile bu ortak özelliği taşıyan kültür, "toplumsal süreç içerisinde var olan, coğrafi koşullar çerçevesinde sürekli değişen, yeniden tanımlanan, yeniden üretilen bir tasarımdır" (Hall, 1994: 222; Kaya, 2011: 31).

Kültürün kimliğin bir ön koşulu, referansı olduğunu düşünmek, pek çok durumla ilgili analizde başlangıç için önemli bir adımdır. ${ }^{10}$ Kültür, kuralcı ve anlatısal, yönlendirici ve nakledici boyutları ile bireylere "biz" deme imkânı verir; bu şekilde, bireylerde kimlik ve aidiyet temelleri yaratır. Aidiyet aynı zamanda, "bireyin kendini ve diğerlerini o aidiyetten kaynaklanan kimliğin gerektirdiği standartlar çerçevesinde tanımlamasını da beraberinde getirir" (Barth, 2001: 17).

\footnotetext{
9 "Dönüşçüler" ile ilgili detaylı bilgi için bkz. Erciyes, J. C. (2008). Adyge-Abkhaz Returnees in the Ancestral Homeland, Diaspora, 17 (3), 340-361; Erciyes, J. C. (2014). 21. Yüzyılda Kafkasya'ya Geri Göç: Adığe-Abhaz Diasporası ve "Dönüş". Sevda Alankuş ve E. Oktay Arı (Eds.), Geçmişten Geleceğe Çerkesler: Kimlik, Kültür ve Siyaset içinde (s. 435-446). Ankara: Kafdav Yayınları. ${ }^{10}$ Her ne kadar hem kültürün hem de kimliğin tanımının yapılması karmaşık olsa da, kültür ve kimliğin arasında vazgeçilmez ve kopması zor bir bağ bulunmaktadır. Buradan hareketle, toplumsal her fenomenin kültürel olduğunu belirtmek, analizlerde yetersiz kalabilir. Bu sebeple, "her şey kültüreldir" ifadesi, bir sonuç olmak yerine yeni sorular ve analizlere kapı açmalıdır.
} 
Aidiyet ile ortak bir geçmişin deneyimlenmesi ve anıları, bu kurallara ve değerlere bağlılık; kendine ait bir algılayış biçimi yaratılır ve bir bağlayıcı yapı oluşturulur. Bu yapı, "hem sosyal boyutta hem de zaman boyutunda birleştirici ve bağlayıcıdır" (Assmann, 2001: 21). Ortak geçmişin ve bu geçmişe ait anıların canlı tutulabilmesi adına, bu kolektif anılar sürekli tekrarlanır ve hatırlanabilir örneklere dönüştürülür; ve kolektif/kültürel hafiza ile aktarılarak kimliğin oluşumunda önemli rol oynar (Tölölyan, 1996). Kültürel hafıza, günlük hafızadan farklı olarak toplumun davranış ve deneyimlerine ait bütün bilginin pratikler doğrultusunda jenerasyonlar arası aktarımını sağlar (Assmann ve Czaplicka, 1995). Grup bu bilgi üzerinden farkındalığını ve tekliğini oluşturarak kimliğini zaman içerisinde yeniden üretebilir hale gelir. Hafiza, sadece geçmişte olmuş olayların yeniden canlandırılması değil, daha çok "içinde bulunan anın dinamikleri tarafından belirlenen ve değişken bir süreçtir” (Özyürek, 2001: 8). Her ne kadar değişmeyen figürler içerse de, tarih içerisinde meydana gelen durumlar kültürel hafiza ile yeniden yorumlanabilir ve bağlanabilir. "Neyin unutulup, neyin hatırlandığı; geçmişin yeniden inşası olarak hafızanın bugüne dair yargılarımızı ve davranışlarımızı belirlemedeki rolü”, kolektif hafızanın önemli bir parçasıdır (Uyan Semerci vd., 2017: 10). Bu belirleme, aynı zamanda pozitif olan "biz buyuz" ve negatif olan "bu bizim karşıtımız" tanımlarını ortaya çıkarır ve kolektif etnik kimliği oluşturur. Kendi özelliklerinin karşıtına sahip olan grup, “öteki” biçiminde şekillendirilir. Bu etkileşim süreçlerinden ortaya çıkan etnisite, etnik kimliğe dönüşerek çeşitli ön yargılar, pozitif ya da negatif düşünceler ortaya çıkarır (Barth, 2001). Aynı zamanda, tarihsel olaylardan etkilenerek ve öğrenilerek, "sembolik” ön yargılara sebep olabilmektedir (Sears, 1988). Bu ön yargıları ve algılama biçimlerini etkileyen bir diğer etmen de, bireylerin veya grupların geçmişte yaşadığı, şahit olduğu veya kendilerine aktarılan ilişkiler ve gelişmelerdir. "Kolektif hafızanın ötekileştirme süreci içerisindeki belirleyici rolü, tarihin sosyal temsillerinin belirli politik sosyalizasyon araçları vasıtası ile yaygınlaşarak ötekine dair bilginin şekillendirilmesi ve iletilmesi açısından kritiktir” (Uyan Semerci vd., 2017: 20). Buradan hareketle kimliğin oluşumu göz önüne alındığında, çeşitli etkileşimler, karşılaşmalar ve diyaloglar sonucu kimliğin sürekli oluşum ve tanımlama süreci içerisinde olduğunu söylemek mümkündür. Bireyin

SAD / JSR

Cilt / Volume 22 Sayı / Number 1 
veya toplumun kimlik tanımlama süreci, tarihsel dönüşüm içerisinde stabil olmayan, sürekli kurgulanan bir ifade ediş sürecidir.

Tanımlama süreçleri ile sürekli değişim ve dönüşüm içerisinde olan etno-kültürel kimlik, aynı zamanda siyasal, toplumsal, coğrafi, ekolojik ve ekonomik gibi bağlamlarla da çok yakından bağlantılı olarak değişir (Barth, 2001). Türkiye'de Çerkesler de, yaşanılan yer, yaş, cinsiyet gibi etmenlerin etkisiyle farklı diasporik deneyimler yaşadıkları gibi, aynı zamanda bu çerçevede farklı etnik kimliklere de sahiptirler:

“Bugün Pınarbaşı’ndaki Çerkes kimliği ile Samsun-Çarşamba’nın Kızılot köyünde geliştirilen Çerkes kimliği birbirinden oldukça farklıdır. Farklı coğrafyalarda ve ekolojik koşullarda yaşayan ve farklı gruplarla etkileşimde bulunan Çerkesler, aynı kabileden geliyor olsalar bile, zaman içerisinde özellikle etkileşimde bulundukları grupların niteliklerine bağlı olarak farklı kimliklenme süreçleri yaşayabilirler" (Kaya, 2011: 9).

Her bir etnik grup için geçerli olan farklı etnik kimliklere sahip olma durumu ile, homojen bir Türk, Kürt veya Çerkes kimliğinin var olmasındansa Türk, Kürt ve Çerkes kimliklerinin var olduğunu söylemek doğru olacaktır (Kaya, 2001: 8).

Türkiye'de yoğun yerleşime sahip olan Çerkesler için, kimliğin paylaşım, değişim ve dönüşüm yerleri olarak dernekler her zaman önemli bir yere sahip olmuştur. İstanbul'da kurulan ilk Kafkas organizasyonu Çerkes Tevaün Cemiyeti, 1908 yılında faaliyete geçerek dil ve kültür alanında çalışmalar yaparken, aynı zamanlarda İstanbul'da Adığe dilinde eğitim veren bir Çerkes ortaokulu açılmıştır. Var olan bütün Kafkas cemiyetleri 1923 Lozan Antlaşması ile, “azınlık” tanımı din üzerinden kurulduğu ve Müslüman gruplar azınlık olarak sayılmadığı için kapatılmıştır (Özgür, 2011: 82). ${ }^{11}$ Bu durum, Çerkeslerin ana dillerini

${ }^{11}$ Lozan'da 'azınlık' meselesi için bkz. Oran, B. (2004). Türkiye'de Azınlıklar: Kavramlar, Teori, Lozan, İç Mevzuat, Içtihat, Uygulama. İstanbul: İletişim Yayınları; Akgönül, S. (2009). Towards Minority Policies Beyond Reciprocity? The EU, Greece and 
konuşamamaları ve bu doğrultuda eğitim kurumları kuramamaları, Türkiye'de doğan kuşağa ana dillerinde isimler verememeleri ve Kafkasya' da soyadı olarak kullandıkları sülale isimlerini resmi "soyadı” olarak alamamaları gibi pek çok probleme sebep olmuştur. Daha sonraki yıllarda, her ne kadar anayasal düzenlemeler çok kültürlü bir ülke yapısını reddetse de, ülkede gelişen liberal düşünce akımı Kafkas örgütlerini de etkilemiş ve Kafkas organizasyonlarının tekrar açılması için zemin hazırlamıştır. 1940'lar ve 1950’lerde yaşanan bu süreç, daha liberal bir anayasa olan 1961 Anayasası ile etkin hale gelmiştir (Chochiev, 2007).

1960’lı ve 1970'li yıllarda Türkiye'de, ekonomik, siyasal ve sosyal alanlarda önemli dönüşümler yaşanmıştır. Şehir merkezlerine yönelen göç akımları ile, ilk olarak köydeki yakın ilişkileri devam ettirme ve kültürel kopuşu engelleme amaçlı kültür dernekleri kurulmaya başlanmıştır. Çerkesler de bu dönemde İstanbul, Ankara gibi yoğun göç alan merkezlerde dernekler kurmaya başlamışlardır. ${ }^{12}$ Daha liberal ve kültürel farklılıkların benimsendiği bu yıllarda doğan diasporanın bireyleri, politik değişimleri, durumları, kültürel değerleri ve çabaları daha farklı yorumlayabilmişlerdir (Erciyes, 2008). Bu esnada "Türklerden her zaman kültürel anlamda farklı olan” kimliğin korunması, siyasal taleplerden ziyade dans ve müzik aracıllğı ile, "kendilerinden olanlarla" tanışma ve paylaşım geceleri düzenlemek üzerinden ilerlemiştir. Yakın döneme gelindiğinde, Çerkes dernekleri ve vakıfları "etno-kültürel temelli kamusal tartışmaların parçası haline gelmiş ve kentsel alanda Çerkes kimliğinin yeniden üretilmesine ve diasporik bilincin gelişmesine katkıda bulunmuştur” (Akdeniz Göker, 2018: 94).

Turkey. Othon Anastasakis, K. Nicolaidis ve K. Öktem (Eds.), In the Long Shadow of Europe: Greeks and Turks in the Era of Postnationalism içinde (s. 191-217). Boston: Martinus Nijhoff.

${ }^{12}$ Kurulan derneklerin ayrıntılı incelemesi için bkz. Taymaz, E. (2001). Kuzey Kafkas Dernekleri. Stefanos Yerasimos (Ed.), Türkiye'de Sivil Toplumu ve Milliyetçilik içinde (s. 451-460). İstanbul: İletişim Yayınları; Toumarkine, A. (2001). Kafkas ve Balkan Göçmen Dernekleri: Sivil Toplum ve Milliyetçilik. Stefanos Yerasimos (Ed.), Türkiye’de Sivil Toplum ve Milliyetçilik içinde (s. 425-450). İstanbul: İletişim Yayınları.

SAD / JSR

Cilt / Volume 22 Sayı / Number 1 
1990'ların başında Abhazya-Gürcistan Savaşı'na (1992-1993) verilen maddi destek ve gönüllülerin savaşa

katılımı ile ${ }^{13}$ diaspora milli değerler etrafında bir araya gelmiş; toplantılar ve komiteler organize edilmiştir (Özgür, 2011). Bu bağlamda, özellikle genç Çerkesler arasında “diaspora” kimliğinin oluştuğunu/kuvvetlendiğini belirtmek yanlış olmayacaktır (Wakizaka, 2012). Her ne kadar 1990 sonrası, dünyada devletlerin bireyler üzerindeki rolünde azalma eğilimi olduğu ve bu sebeple diasporaların kendilerini sosyal ve siyasal anlamda ifade etmek için daha fazla firsatları olduğu belirtilse de (Tölölyan, 1996), 90’lı yıllarda Türkiye'deki etnik gruplar birbirlerinden farklı örnekler ve deneyimler yaşamışlardır.

2000'li yıllarda oluşan Çerkes federasyonları, Türkiye'deki Çerkes derneklerini kavrayabilmek açısından önemli oluşumlardır. Kurulan dört federasyona kısaca değinmek, yapılan görüşmeleri ve bağlamlarını anlamlandırmak açısından daha faydalı olacaktır. ${ }^{14} 2003$ yılında kurulan Kafkas Dernekleri Federasyonu (KAFFED), 1970’lerde başlayan Türkiye'deki Kafkas derneklerini merkezi bir örgütte toplama çaba ve çalışmalarının en etkili adımlarından biri olmuştur. Elli iki üye derneği ile en kapsamlı federasyon olarak akademik/kültürel yayın ve faaliyetleri ile çalışmalarına devam etmektedir. Bu anlamda KAFFED'i, Türkiye'deki Çerkeslerin temsiliyet gücü açısından oldukça önemli bir sivil inisiyatif olarak değerlendirmek mümkündür. Birleşik Kafkasya Dernekleri Federasyonu (BIRKAFFED), birleşmiş tek bir Kafkasya devleti ideası ile yola çıkmış, 1918'de kurulan Birleşik Kafkas Cumhuriyeti (United Caucasus Republic) fikrini savunarak 2004 yılında kurulmuştur. Bünyesinde Adığe ve Abhaz üye derneklerin yanı sıra Çeçen, Karaçay ve Balkar dernekleri de bulunmaktadır (Özgür, 2011: 83). ÇerkesFed (Çerkes

13 90’lı yıllardaki çatışma ile Kafkas diasporanın Türk Dış Politikası ile etkileşim sürecinin detaylı analizi ve yine bu dönemde kurulan KADK (Kafkas-Abhazya Dayanışma Komitesi)'nin detayları için bkz. Çelikpala, M. (2005). Türkiye'de Kafkas Diyasporası ve Türk Dış Politikası'na Etkileri, Uluslararası İlişkiler, 2 (5), 71-108.

14 Türkiye'deki Çerkes diasporasının politik ve sivil toplum hareketlerinin daha kapsamlı anlaşılması için bkz. Besleney, Z. A. (2016). Türkiye'de Çerkes Diasporasının Siyasi Tarihi. İstanbul: İstanbul Bilgi Üniversitesi Yayınlar1; Özgür, E. (2013). Türkiye'deki Kuzey Kafkas Diaspora Kurumları ve Lobi Faaliyetleri. Mehmet Hacısalihoğlu (Ed.), 1864 Kafkas Tehciri: Kafkasya'da Rus Kolonizasyonu, Savaş ve Sürgün içinde (s. 551-592). İstanbul: Yıldız Teknik Üniversitesi Balkan ve Karadeniz Araştırmaları Merkezi. 
Dernekleri Federasyonu), 2013 yılında büyük nüfuzu olan KAFFED’den ayrılarak yeni bir yol çizmeye başlamıştır. Federasyonun gerekliliği, isim tanımı ve diasporaya etkileri halen oluşumlar içerisinde tartışılmaktadır.15 2010 yılında Abhaz Dernekleri Federasyonu'nun kurulmasıyla, uzun süredir tartış1lan “Çerkes-Abhaz” kırılmasının önemli bir sonucu ortaya çıkmıştır.16 Federasyon, Abhazya’nın uluslararası düzeyde tanınması için yapılması gereken çalışmalara öncelik verilmesi gerektiğini savunarak ayrı bir yol çizmeye karar vermiştir. Türkiye'de yaşayan Çerkeslerin Abhazya ile ilişkileri arttıkça, Çerkes diasporik kimlik bilincinin ve Kafkasya’ya duyulan ilginin arttığını söylemek mümkündür. Bu anlamda, federasyonlar dışında çeşitli platformlar da diasporik kimlik bilincinin oluşması ve şekillenmesine dair çalışmıştır. Türkiye' deki Çerkes diasporası için önemli paylaşım alanlarından biri olan Jineps dergisinin, birbirlerinden farklı görüşlere sahip olan Kafkasya Forumu, Kafkasevi, Cherkessia.net gibi platformların da, farklı kimliklere sahip Çerkes toplumunun bir yansıması olduğu belirtilebilir.17

2000’li yıllarda Türkiye’nin Avrupa Birliği sürecine hız vermiş olması, demokratik açılım süreci bağlamında ana dilin öğretilmesi için oluşturulan kurslar ve üniversitelerde açılan azınlık dilleri kürsüleri, ana dilin seçmeli ders olarak ilkokullarda öğretilmek üzere müfredata girmesi, Kürtçe yayın yapan TRTŞeş kanalının yayına başlaması, Çerkeslerin kimlik taleplerini etkileyen önemli gelişmeler olmuştur. Bugüne kadar dernekler yolu ile dile getirilen kültürel ve siyasi talepler, iktidarın değişen söylemleri, Cumhuriyet'in ilk yıllarına ait politikalar ile yüzleşilmeye niyetlenilmesi, Kafkasya'daki Soçi Olimpiyatları ve şiddet olayları ile farklı bir açıdan ele alınarak ortaya konmaya başlanmıştır. Anayasa değişim süreci ile yüksek sesle ortaya çıkan dil talebi, dernekler ve benzer oluşumlar doğrultusunda Çerkeslerin politizasyonunun işaretçisi olmuştur. Siyasal olarak en önemli gelişim sayılabilecek adımları da, 2014

\footnotetext{
${ }^{15}$ Proje çerçevesinde derneklerde, şehirlerde ve köylerde yapılan kanaat önderleri görüşmelerinde de bu konuya değinilmiştir.

${ }^{16}$ Besleney'in (2016: 30) belirttiği gibi, “Abhaz ve Adığe kimlikleri ise son yirmi yılda birbirlerinden farklılaşmıştır ve bugün çok az sayıda Abhaz kendi ulusal kimliğini Çerkes terimi çerçevesinde tanımlar” (italik orijinal).

${ }^{17}$ Federasyonlar ve diğer oluşumlar özelindeki farklılıkların ayrıntıları için bkz. Wakizaka, 2012.
}

SAD / JSR

Cilt / Volume 22 Sayı / Number 1 
yılında Çoğulcu Demokrasi Partisi’nin kurulması ile belirmiştir. Her ne kadar 2015 yılında yapılan genel seçimin sonuçlarına göre partiye verilen desteğin Çerkes halkınca yoğun olmadığı görülse de, diasporaya ait dernekler ve benzer oluşumlarda parti oluşumunun tartışılan başlıklardan bir tanesi olduğu bilinmektedir.

Bugün Türkiye'de Çerkesler, Türkiye'de “etnik azınlık” statüsünü kazanmak, Kuzey Kafkasya cumhuriyetleri ile ilişkileri geliştirmek, ana vatanları olan Kafkasya'da sosyo-ekonomik, siyasi ve yasal durumları yaratmak ve geliştirmek gibi amaçlar doğrultusunda derneklerde pek çok çalışmalar yapmaktadırlar (Chochiev, 2007: 226). Türkiye'de yapılan çalışmaların son örneklerinden biri olarak dernekler (ve dolayısıyla federasyonlar), Suriye İç Savaşı sonucu Türkiye’ye göç etmek durumunda kalan Suriyeli Çerkeslere yapılan yardımların planlama merkezi olmuştur. Yardımların planlanması, Türkiye’ye göç etmek durumunda kalan Suriyeli Çerkeslerin dernekler vasıtasıyla köy ve şehirlerde çeşitli evlere yerleştirilmesini de kapsamıştır. Aynı zamanda, halen Kafkasya'da maddi yardıma ihtiyacı olan aileler için de dönem dönem yardımlar toplanmakta ve bu ailelere iletilmektedir. Bu yardımlaşma durumu, Vertovec (1997)'in diasporanın ana vatan ile ortak bağlara sahip olduğunun ve bu bağların ulus-aşırı iletişim yarattı̆̆ının; ve Safran (1991)’’n diaspora bireylerinin farklı ülkelerdeki aynı etnik kökene sahip insanlarla bağl1lık/dayanışma içerisinde olduğunun ve ulus-aşırı bağlardan oluşan dayanışma duygusuna sahip olduklarının bir örneğidir.

Türkiye' de sayıca artan Çerkes dernek ve platformlarında yeni bir iş bölümü meydana geldiğini belirtmek mümkündür: daha yeni organizasyonlar politika ve lobileşme üzerine aktivitelerde bulunurken, daha eski organizasyonlar kültür temelli aktivitelere öncelik vermektedir. 18 Çerkes örgütlenmelerinin bu denli çeşitli olması; Kuzey Kafkasyalı halkların çeşitliliği, sürgün edilen bu halkların Türkiye'nin pek çok yerine

\footnotetext{
${ }^{18}$ Hansen, L. F. (2012). Renewed Circassian Mobilization in the North Caucasus 20-years After the Fall of the Soviet Union. Journal on Ethnopolitics and Minority Issues in Europe, 11 (2), 103-135.
}

$\mathrm{SAD} / \mathrm{JSR}$

Cilt / Volume 22 Sayı / Number 1 
dağılmış olmaları, sahip oldukları farklı politik eğilimler ve düşünsel farklılıklar sebepleriyle de açıklanabilir (Grassi, 2017: 147).19 Çerkesler her ne kadar Türkiye'nin muhtelif yerlerine yerleştirilmiş olsalar da, belirli bölgelerde birbirlerine yakın yaşamaları ve yakın köyler arası akrabalık ilişkilerinin bulunması da diasporanın kültürel kimliğini korumasında önemli bir rol oynamıştır.20 Burada tekrarlamak gerekir ki, Çerkeslerin kolektif diasporik kimliklerinin korunmasına yönelik durumları gözlense de, kimliğin değişmez ve tek bir etmenden oluştuğunu söylemek mümkün değildir. Bu nedenle, Çerkeslerin kimliğe dair konumlanmaları ev günlük/siyasi değerlendirmeleri yaşanılan bölge, Türklük ve Müslümanlık algısı, ideolojik yönelim, yaş ve cinsiyet gibi pek çok faktöre bağlı olarak değişiklik göstermektedir. Bu durum da aslında, görüşmelerde kişilerin kendilerini tanımlamaları sırasında verdikleri farklı değerler ve referansların sebebini de açıklamaktadır.

\section{KİMLİĞİN DÖNÜŞEN İNŞASI: ÇERKESLERDEN KÜRTLERE ATIFLAR}

Kürt hareketinin Ortadoğu'da gösterdiği bağımsızlık talebi ve eylemleri, aynı topraklarda Çerkesler için söz konusu olmamıştır. Ana vatanları olan Kafkasya bölgesinden sürüldükten sonra Çerkesler, Ortadoğu coğrafyasında bağımsızlık etmenleri içeren taleplerde bulunmamışlardır.21 Fakat ana vatanları olan Kuzeybatı Kafkasya bölgesinde 90’lı yıllara kadar uzanan bağımsızlık mücadeleleri, halen diplomatik açıdan devam etmektedir. Buradan hareketle, çalışma kapsamında incelenen konu, farklı talep ve tartışmaları olan Çerkes ve Kürt halk hareketlerinin kıyaslanması değildir. Çalışma, Türkiye coğrafyasındaki Çerkes diasporasına ait derneklerden yola çıkarak, dernekler içerisindeki Çerkeslerin

\footnotetext{
${ }^{19}$ Özellikle diasporaya ait dernek ve kuruluşların, sürgünün tanımlaması ve içeriği üzerine tartışmaları devam etmektedir. Kimi kuruluşlar, bazı kanallar üzerinden yaşanılmış olan katastrofik olayı "soykırım" olarak tanımlama ve tanıtma amaçlı faaliyetlerde bulunmaktadırlar.

${ }^{20} \mathrm{Bu}$ konuda detaylı çalışma için bkz. Sunata, U. (2015). Diasporanın Sosyokültürel Hafızası Olarak Çerkes Köyü. Sosyokültürel Yönleriyle Çerkes Toplumu içinde (s. 9-48). Ankara: Kaf-dav Yayınları.

${ }^{21}$ Grassi, Türkiye'de bulunan bu "kültürel mücadelelerin sonunda bir toprak talebine dönüşebileceği korkusu”nu, Çerkes sürgününün tanınmasını frenleyen bir faktör olarak yorumlamıştır (2017: 148).
} 
kendilerini ifade ediş biçimlerinde var olan Kürt toplumu ve Kürt hareketi atıflarını incelemektedir. Ulusal veya toplumsal bilinçten yola çıkarak diasporik bir toplum ile ana vatanında yaşayan bir halkı karşılaştırmak da, yöntemsel açıdan doğru olmayacaktır.

Kimliğe dair ifadeler ve politik konumlanmalar konusunda Kürt halkına yapılan atıflara bakıldığında, dernekler içerisindeki Çerkeslerin Kürt halkını ve hareketini iki ana başlık çerçevesinde ifade ettiğini belirtmek mümkündür: “ötekilik” ve "benzerlik”. Kürt halkını ve hareketini karşıt bir var oluş, bir düşman şeklinde nitelendiren Çerkesler, bu referansları Kürtlerin terör ile anılması, iki halkın hareketleri arasındaki talep farklılıkları ve "ötekiye” ait oluşmuş ön yargılar üzerinden kurmuşlardır. Kurulan benzerlik açısından bakılacak olursa, özellikle Cumhuriyet'in ilk yıllarında yaşanılan zorluklar, ana dilin kullanımı ve bu konudaki güncel talepler, Çerkeslerin Kürt halkı ve hareketi ile ortak noktalar bulmasına sebep olmuştur.

\subsection{Farklılıkların Vurgusu: "Birlikte Anılmak İstemiyoruz"}

Osmanlı Devleti topraklarına sürgün edilen Çerkeslerin, yürütülen iskân politikaları kapsamında çeşitli yerlere yerleştirilmeleri, diasporik kimliği koruma çabalarına rağmen kültürel ve dilsel kopuşlara neden olmuştur (Kaya, 2011). İskân politikaları sonucunda Anadolu boyunca kuzeyden güneye uzanan hat, Marmara civarında daha dağınık yerleşimler şeklinde görülmektedir. Bu dağılmışlık durumunun ana dil bağlamında ifade edilişi, Kürtlerin ana dil bilgisi ile kıyaslanabilmektedir:

“Bugün Kürtlerin hepsi bir arada yaşıyor, küçücük çocuk bile Kürtçe konuşabiliyor, ama maalesef Çerkesler Türkiye’ye parça pinçik yerleştirildikleri için bu durum Kürtlerdeki gibi değil” (BG, Tokat).

Her ne kadar bu dağınıklığın kültürel birlikteliğe etkileri olduğunu söylemek mümkünse de, özellikle son iki kuşakta görülen dil kaybının etkilerini, 1960’lardan başlayan köyden kente göç süreci ile açıklamak daha doğru olacaktır. Yapılan görüşmelerde, gençlerin ve yaşlıların yeni neslin Çerkes dilini bilmemelerine dair yaptıkları pek çok referans bulunmaktadır: 
"Her dilin ve her kültürün de korunmasını istiyoruz biz; Çerkes olarak istiyoruz bunu. Kürtlerin Türkiye'den istedikleri ana dil, haklı bir istek, evet arkasındayım. Almanya'daki Türklerin durumunu düşünün, Almanya' daki Türkler Türkçe eğitim istiyor değil mi? Bunu anlayabilen kesim neden ana dilde eğitimi anlamıyor? Sorum bu benim. Başbakan bile açıklama yapıyor; ‘Almanya'da ana dilinizi alın' diye, 'Türkçe'yi unutuyorsunuz' diyor. E ben de kendi dilimi unutmak istemiyorum. Eğitim dilim de olsun istiyorum; ana dilimi korumak da istiyorum. Kürtlerin bu anlamdaki istek ve taleplerini de gerçekten destekliyorum. Şu da bir gerçek; biz Kürtler kadar dilimizi koruyabilmiş değiliz. Sebebi de Kürtlerin şehirlerde hep bir arada yerleşim halinde olmaları; mesela bir Adana hep Kürt. Bizim böyle bir şehrimiz yok, köylerdeyiz ve şehirlerde birlikteliğimiz dernekler etrafında oluyor. Hani bir Kayseri hep Çerkes olsa mesela, dilimiz çok güzel olabilirdi; ana dil problemimiz bu kadar olmazdı. Çok daha canlı korunabilirdi” (DG, Adana).

Özellikle genç kuşakta Çerkes dilinin bilinmiyor olmasının çözümlerinin bulunabilmesi konusunda, Çerkeslerin yaklaşımlarını Toksabay (2005: vii)'ın şu ifadeleri açıklıyor:

“Genel olarak, dil politikası Kürt gruplar için bir tanınma meselesi olarak algılanırken, Çerkes gruplar için en önemli sorun dilin geliştirilmesi ve topluluğun dil kullanımını arttırmasıdır. Dolayısıyla, Kürt gruplar dillerinin Türkçe ile eşit statüde görülmesini talep ederken, Çerkes grupların talebi dilin eğitilmesi ve geliştirilmesi için destek verilmesi üzerinde yoğunlaşmaktadır”.

Bu tespitin örneğini bir görüşme üzerinden vermek mümkündür:

““Ana dilde eğitim' demekten ziyade ‘ana dil eğitimi’ demek daha mantıklı olur. Çünkü 'ana dilde eğitim’ denilince insanın aklına Kürtçe, Çerkesçe ya da Lazca fizik dersi, matematik dersi, edebiyat dersi görmek gibi bir şey geliyor ve bunun şu günün koşullarında çok bir geçerliliği yok ama dil eğitimi, profesyonel anlamda dil eğitimini vermeliyiz" (NY, Eskişehir). 
Çerkes dili eğitimi, Çerkes alfabesinin orijinalinin Kiril harflerinden oluşması, dilin birçok diyalekte sahip olması ve yazılı olarak değil, kulaktan kulağa aktarılması (Kaya, 2011) gibi zorluklara rağmen, genç kuşakta diasporik bilincin hız kazanması ve derneklerin faaliyetleri ile sürdürülmektedir.

Çerkeslerin Kürt halkını ve hareketini farklılıklara vurgu yaparak negatif algılar etrafında yorumlamasının, "Kürtlerin bağımsızlık talepleri” çerçevesinde toplandığı da olmuştur. Bugün, Kürt halkının siyasi temsiliyetinin önemli bir figürü olarak Halkların Demokratik Partisi (HDP) karşımıza çıkmaktadır. ${ }^{22}$ HDP'ye verilen referanslar, Kürt hareketi ile Çerkes hareketinin taleplerinin farklılıklarının belirtilmesinde dikkat çekmektedir. Çerkesler, siyasal ve sosyal taleplerinin etno-kültürel temelli olduğunu (Akdeniz Göker, 2018), ve Kürt hareketinin taleplerinden ayrıştığını vurgulamışlardır:

“Amaçlarımız farklı; onlar bağımsızlık istiyor, toprak istiyor, ayrı bir Kürt bölgesi istiyor. Bizim öyle bir talebimiz yok; ulaşmak istediğimiz sonuçlar farklı. O yüzden birlikte hareket edilmesini doğru bulmuyorum. Bir haberde, 'Kürtler ve Çerkesler birlikte, ikisi de bağımsızlıklarını istiyorlar' denmesini istemem" (ST, Adana).

“Kürtlerin Türkiye'den istedikleri ile bizim Türkiye’den istediğimiz aynı değil. Biz Türkiye’yiz zaten; bakın biz kendimizi Türkiye'den ayrı görmüyoruz. Biz Türkiyeliyiz, Türkiye’nin çıarları bizim de çıkarlarımız. Sadece Kürtler ana dilde eğitim istiyor, ben de istiyorum; onun haricinde ayrışıyoruz biz (DG, Adana).

Bunun yanı sıra, talep edilen hakların “yanlış yorumlanabileceği” düşüncesi belirtilmiş, ve Kürtlere yapılan atıfların "bölücü olma fikri” ile birleştirildiği durumlar olmuştur. Bu durum, etnik kimliğin bir parçası olan

\footnotetext{
${ }^{22}$ Buradan hareketle, Kürt halkının tüm temsiliyetinin tek bir partiye ait olduğunu söylemek doğru olmayacaktır. Önemli olan, görüşmelerde Kürt hareketine verilen referansların pek çok anda HDP ile birleşmesidir. Bir diğer not edilmesi gereken de yapılan görüşmelerin, HDP'nin \%10 barajını geçtiği 2015 genel seçimlerinden önce yapılmış olmasıdır. Dolayısıyla, güncel gelişmelerin görüşmecilerin fikirlerine etki etmiş olabileceği göz önünde bulundurulmalıdır.
} 
negatif atıflar, referanslar, düşünceler ve ön yargıların (Barth, 2001), kültür ile birlikte sürekli yeniden üretildiğini (Hall, 1994; Kaya, 2011) göstermesi açısından önemlidir:

“Korku var işte, ülkede Kürtlere karşı bakış açısı belirli. Türkiye’de genel bir kesimin 'bunlar bölücü, bunlar vatanı bölmek istiyor' düşüncesi var. Bu da 'aman bizi de onlarla aynı kefeye koymasınlar' gibi düşüncelere neden oluyor" (NY, Eskişehir).

Bir görüşmeci, belirtilen korkunun sebebi ve Çerkesler için bu korkunun ne anlama geldiğini kolektif hafiza üzerinden tanımlamıştır. $\mathrm{Bu}$ örnek ile, diasporik toplumun günlük hayatındaki etmenlerin toplumsal hafızadan nasıl etkilendiğini (Özyürek, 2001) görmekteyiz:

"Şöyle bir gerçek var önümüzde; insanların Çerkes olduğunu söylerken çekince yaşadığı bir dönemdeyiz. Niye? Kürt örneğinden hareketle bakarsak, Türk toplumunun genelinde Kürtler ayrılıkçı bir statüye sahip olduğu için. Yani kişi ‘Kürtüm' demenin, o kişinin toplumla tamamen bağlarını kopardığı anlamına geldiğini düşünüyor. Kendisi de 'Çerkesim' dediği zaman, ‘ben de Kürtler gibi olur muyum? Bana da bölücü derler mi?’ düşüncesi çıkıyor. Bu, toplum tarafindan karşı1ık bulan bir şey; insanları bu algıya iten şey, toplumda karşılaştıkları durumlar. Etnik anlamdaki mücadelene ‘bölücü' yaftası yapıştırıldığg için, sen çıkıp ‘Çerkesim' diyemiyorsun. Bu tabii bizim toplumumuzun yaşamış olduklarıyla da ilgili. Hani bir kişiye 40 kere 'deli' dersen deli olduğunu hisseder ya; bize de 40 yıl boyunca 'hain' dendi tarih kitaplarında. O 'hain' kelimesinin psikolojik etkisidir; biz kültürümüzü ve kimliğimizi ifade edemiyoruz"23 (KT, Çorum).

İfade edilen negatif referanslar, Çerkeslerin kısıtlı ana dil bilgileri, ana dili eğitimi taleplerinin farklı temelli olması, siyasal ve sosyal taleplerinin farklılaşması, ve bunlara ek olarak ortaya konulan taleplerin "yanlış yorumlanabileceği korkusu" başlıkları altında toplanabilmektedir. Bu referanslar, diaporik bir toplumun

${ }^{23}$ Görüşmeci burada, “Çerkes” Ethem Bey’den bahsetmektedir. 
kolektif kimlik oluşum ve dönüşüm süreçlerinde “öteki”nin önemli bir yer kapladığını, gruba “biz” deme imkanı verdiğini, ve bu dönüşümün sürekliliğini görmek açısından önemlidir.

\subsection{Ortak Noktalar ve Benzerlikler: "Kürtler Kürt'üm Demeye Utanırlardı, Çerkesler Çerkes'im Demeye"}

Yapılan görüşmelerde her ne kadar farklılıkları kapsayan temalarda her yaş grubundan Çerkesin ortak noktada buluşabildiği görülse de, benzerliklere verilen referansların daha çok gençler tarafindan vurgulandığını belirtmek, dernekler özelinde Çerkesleri daha iyi analiz edebilmek açısından faydalı olacaktır. Bu anlamda yapılan en önemli benzetmelerden bir tanesi, özellikle Cumhuriyet'in ilk yıllarından başlayarak, iki halkın da yaşamış olduğu ana dil sorunudur. Bu sorun vurgulanırken, görüşmeciler hem siyasal hem de günlük alandan yaşadıkları veya kendilerine aktarılan zorluklara örnekler vermişlerdir:

“Devletin bu işe el atması ve bize destek vermesi gerekiyor. Aslında Türkiye’ de Çerkeslerle Lazlar, Türklerden sonra 'bunlar da var' diye anılır. Fakat biz de çok ciddi sıkıntılar yaşadık bu topraklarda; pek çok etnik halkın yaşadığı sıkıntıları biz de yaşadık. Bizim de dilimiz yasaklandı, konuşmamız yasaklandı, köy isimlerimiz değiştirildi, sülale adlarını kullanmamız yasaklandı” (NY, Eskişehir).

Cumhuriyet'in ilk yıllarından itibaren uygulanan ulus-devlet politikaları, etno-kültürel halklar için çeşitli şekillerde etkisini göstermiştir (Kaya, 2011). Bu durum, tarihsel süreç içerisinde aktarılmakla birlikte, halkların toplumsal hafizasında yer tutmuştur:

"Bir grubu yaftalamak için bazı olaylar kullanıldı. Kürtler için de Şeyh Sait ya da başka isyanlar kullanılmıştır. Ermeniler için de Taşnak Cemiyeti’ni örnek vermişler, oradaki önde gelenlerden birisine hain demişlerdir. Ethem Bey’in başına da 'Çerkes’i koydular. Aslında bu, Türk devletinin uluslaşma politikasındaki taktiklerinden birisidir” (HK, Samsun).

Türkiye'ye sürgün edilen Çerkesler, Türkçe bilmemelerine rağmen devlet gözünde Pomaklar ve Arnavutlar gibi “Türk" sayılsalar da, kültürel ve dilsel anlamda Türklüklerinin çeşitli iskân politikalarıyla 
“geliştirilmesi” gerekmiştir (Kirişçi, 2000). ${ }^{24}$ Her ne kadar “ev sahibi toplumla ortak paydayı teşkil eden İslâm dininin varlığı, dolayısıyla Osmanlı Millet sisteminin ${ }^{25}$ aynı bloğunda yeralma durumu, Çerkesleri gayri-Müslim azınlıklara oranla daha avantajlı bir konuma" getirse de (Kaya, 2011), Osmanlı Devleti'nin iskân politikalarının ardından Cumhuriyet'in ilk yıllarında görülen azınlıklara yönelik ulus-devlet politikaları, Çerkeslerin de gündelik hayatını pek çok anlamda etkilemiştir. "Vatandaş Türkçe Konuş!" politikası 1920'lerde başlayıp 1937 yılında en etkin haline gelmiş, azınlıkların tek dilli bir topluma katılmalarını ve kamusal alanlarda Türkçe konuşmayı zorunlu hale getirmiştir (Toksabay, 2005). Çalışma kapsamında yapılan görüşmeler ve sohbetlerde, özellikle 50 yaş ve üstü erkeklerin bu sıkıntıları sadece okullarda yaşamadıkları, Çerkes öğretmenlerinin evlerinde konuştukları Çerkesçe’ye dâhi müdahale ettiği belirtilmiştir:

“Ben ilçede doğdum, babam ticaretle uğraşıyordu. Büyüdük okula başladık 1957'de; Türkçe bilmiyorum. Okulda herkes bir şeyler söylüyor ama anlamıyorum; çok büyük sıkıntılar yaşadık. Çerkesçe konuşmak yasaktı, gizli başkanlar seçmişti öğretmen. Çerkesçe konuşanları yazıyorlardı, götürüyorlardı bizi öğretmene veriyorlardı. Öğretmen bizi tahtaya diziyordu, 'sen Çerkesçe konuşmuşsun' diyordu; bizi dövüyordu. Zar zor Türkçe’yi öğrendik; affedersiniz ‘tuvalet’ demeyi bilmiyorduk mesela, o bile büyük sorundu. Mümkün oldukça Çerkesçe’yi tamamen yasaklamışlardı. Çoğu zaman ‘Çerkesim' demeye utanır olmuştuk, korkuyorduk. Çocuklar dalga geçerlerdi, derlerdi ki 'halburun (kalburun) içine taşları koymuşlar, çalkalamışlar çalkalamışlar ‘Çerkes’ olmuş'. Kürtler Kürt’üm demeye utanırlardı, Çerkesler Çerkes’im demeye utanırlardı; çünkü Türkler bizi çok aşağılıyorlardı o zaman. Bunda Çerkes Ethem olayının da büyük etkisi

\footnotetext{
${ }^{24}$ Kaya (2011: 11), Çerkeslerin çoğunlukla Müslüman olmasından kaynaklı olarak "Türk kavramı içerisinde asimile edilmeye çalışıldığını", ve bu sebeple farklı bir etnisiteden geldiklerinin yakın zamana dek göz ardı edildiğini belirtir.

${ }^{25}$ Millet sistemi ile ilgili detaylı çalışma için bkz. Karpat, K. (2017). Osmanlı'da Milliyetçiliğin Toplumsal Temelleri. İstanbul: Timaş Yayınları.
} 
vardı; Çerkes Ethem'i tarih kitapları genelde vatan haini olarak göstermişler” (AA, Kahramanmaraş).

““Herkes Türkçe konuşacak veya herkes Türk'; böyle bir dünya yok, zaten olması da imkânsı. Fakat Çerkesce konuşulan yerlerde öğretmenlerin öğrencilere baskıları ile, dayakları ile, Çerkesce konuşanların gözaltına alınmaları ile bu yapılmaya çalışıldı bir dönem. Bu sadece Çerkeslere uygulanmadı, yani bu ülkede zulme uğramamış çok az kesim vardır; solcusu da ülkücüsü de uğradı darbe dönemlerinde, Aleviler de, Kürtler de uğradı ama Çerkesler de uğradı” (BG, Tokat).

Çerkes dilinin günlük hayatta kullanılması ile ilgili yaşanmış sıkıntılara ek olarak, yukarıda bahsedilen alfabe, diyalekt ve aktarım biçimi zorlukları ile, günümüzde dilin eğitimi de tartışma konusudur. Ana dili eğitimi ile ilgili bu tartışmalara, Kürtçe ile benzerlikler kurularak örnekler verilmiştir:

“Biz beraber savaşmışı, hepsini Çanakkale'de alt etmişiz, destan gibi bir zafer kazanmışı hep beraber. Bu savaşta yendiğimiz milletlerin dilleri üniversitelerde okutuluyor, kolejleri var, liseleri açılıyor; ama Çerkes, Kürt veya Laz, yani beraber savaşanların dilleri öcüymüş gibi görülüyor. Yani İngilizce veya Fransızca konuşunca çağdaş, liberal oluyorsun; ama Kürtçe, Çerkesce konuştuğunda bölücü oluyorsun! Bu zihniyetin değişmesi lazım” (BG, Tokat).

“Kürtlerin de ana dil istemeleri en doğal hakkıdır; nasıl Türk Türkçe'yi istiyorsa Kürt de Kürtçe'yi ister. Öğretmenlik yapmışım bir sürü öğrenci yetiştirmişim, bugün iş yerim var, adam çalıştırıyorum, devlete vergimle katkıda bulunuyorum. Niye benim dilim unutulsun ki? Kürt de vergisini veriyor, vatanına askerliğini yapıyor, hepimiz bu vatana hizmet ediyoruz. Madem hepimiz bu topraklarda doğduk, hepimiz eşit haklara sahip olmalıyı”"(AA, Kahramanmaraş).

Eşit haklar çerçevesinde bugün ortaöğretimde Çerkesçe'nin seçmeli ders olarak alınabilmesi ve üniversitede dil bölümlerinin açılması doğrultusunda yaşanılan gelişmelere ve politik ilerlemelere bakıldığında, siyasi gücün Avrupa Birliği’ne uyum süreci ve Kopenhag Kriterleri kapsamında adım 
atmadığını söylemek ne kadar doğru olmayacaksa; tüm gelişmeleri sadece bu etmene bağlamak da analiz açısından bir o kadar doğru olmayacaktır. Türkiye’nin etno-kültürel çeşitliliği içinde Avrupa Birliği’ne entegrasyona yönelik politikaları, “çeşitliliğin ideolojik bir söylem olarak ivme kazandığını” (Kaya, 2011: 16) gösterebilecekken, Türkiye'nin bu sürecinde Çerkeslerin kazanımlarını daha farklı yorumlayanlar da olmuştur:

“Belki Kürtlerin arkasına vagon olarak taktılar bizi. Belki Avrupa’ya karşı, 'siz bastırıyorsunuz diye değil de, biz kendi demokratikleşme sürecimiz altında tüm halklara bunu yapıyoruz' demek için bunu yapıyorlar. Bunlar bizim taleplerimiz ve verdiğimiz çabalar yüzünden, bizim emeklerimiz sayesinde olmadı. Tamamen başka bir topluluğun üzerinden faydalanıyoruz biz belki, ama bir şeyler yapılıyor" (NY, Eskişehir).

“Kürt hareketi Çerkeslerin 'ne oluyoruz' demesini etkilemedi, ama bugün okullarda seçmeli Adığece, Abhazca dersleri veriliyorsa Kürt hareketinin bunda büyük payı ve etkisi vardır. Buna Kürt hareketi mi dersiniz, yoksa devletin normalleşme süreci mi dersiniz, o da tartış1lır. Kimileri 'Kürtler olmasaydı bu dersleri vermeyeceklerdi, onlar yaptılar da oldu' diyor, diğerleri de 'e devlet olmasaydı, bu hükümet olmasaydı veremezlerdi’ diyor” (BG, Tokat).

"Kürtlerin kültürel temelde başlayıp, sonradan politikaya evrilen bir mücadele süreci var. Sen Çerkesler olarak - bıraktım Kürtlere ya da başka bir insani veya demokratik mücadeleye desteğikendin bir siyaset üretemedin. 'Ben ana dilimde konuşmak istiyorum' lafinı on sene-on beş sene önce etmiyordun sen. Şimdi çıkıyorsun 'biz Kürtler gibi değiliz, biz çok farklıyız, onlar toprak talebinde olabilirler, demokratik özerklik talebinde bulunabilirler; bizi başkalarıyla karıştırmayın’ diyorsun” (HK, Samsun).

İki farklı konu başlığı altında ele alınabilecek referansları veren görüşmecilerin, aynı zamanda iki ana yaklaşım benimsediği de ifade edilebilir. Daha devletçi ve muhafazakâr görüşe sahip olan Çerkes dernek 
yöneticileri ve kanaat önderleri, Türkiye'ye uyum sağlandığını düşünerek; Çerkeslerin Cumhuriyet'in ilk yıllarında, özellikle Kurtuluş Savaşı'nda oynadıkları rollerle Türkiye’ye bağlılıklarını ortaya koyduklarına dair atıflarda bulunmuşlardır.

Bilinmektedir ki; otoriter figürlere ve geleneksel değerlerine bağlı gruplar, bu etmenler ile kendilerindenolmayan gruplara karşı negatif görüşler barındırabilmektedirler (Adorno vd., 1950). Buna ek olarak, daha çok muhafazakâr, milliyetçi ve devletçi Türklerin Kürtlere karşı olumsuz referanslar ortaya koyduğu düşünülürse, daha muhafazakâr ve kendini “aynı zamanda Türk olarak” tanımlayan Çerkeslerin benzer referansları verdiğini görmek tutarlıdır (Dixon ve Ergin, 2010).

Buna karşın, daha radikal ve eleştirel düşünceye sahip olan Çerkes dernek yöneticileri ve kanaat önderleri Osmanlı Devleti'ni, iskân politikasını, Cumhuriyet'in ilk yıllarındaki Türkleştirme politikalarını (ana dillerinin yasaklanmasını vb.) ve devam eden Çerkes devletçi yapısını eleştirmektedir. Kendilerini “Çerkes olmanın yanında Türk de olan” bireyler olarak tanımlayan Çerkeslere yönelik eleştirel bir tavır alınarak, bu durumun diasporik bilinç ile bağlantısı kurulmuştur:

"Yani, burada bilinç çok önemli aslında. Mesela bizim köylerimizde ulusal bilinç çok fazla yok. Ulusal bilincin olmadığı yerlerde, bizde mesela, Kürt düşmanlığı da vardır. Türkiye’de nasıl MHP’li ya da Türkçü vardır, o farklı bakar. Bizde de ulusal bilinci çok fazla olmayan insanlarda Kürtlere bir MHP'li nasıl bakarsa öyle bakan da var, Ermenilere de bakan var. Fakat ben bir Kürt Kürtçe konuştuğunda çok mutlu oluyorum; çünkü kendi dilini konuşuyor” (MB, Samsun).

Bireylerin kendilerini Çerkes olarak tanımlama hali de, çalışmanın başında belirtildiği gibi çeşitli anlamlar barındırmaktadır. Bir görüşmeci, bu durumu anlatırken de Kürt halkı ile bir benzerlik kurarak, duruma farklı bir açıdan yaklaşmıştır: 
“Birileri bize diyor ki 'Çerkes eşittir Adığe', birileri de diyor ki 'hayır kardeşim, Çerkes eşittir Adığe değil, Çerkes eşittir herkes'. Bunun tanımını yapmak için birilerinin birilerine bask1 kurmasına gerek yok. Bu şeye benziyor, hani “Kürt yoktur, 'kart’tan 'kurt’tan gelmiştir” (gülüyor), bilmem ne olmuştur. Sen bir insana 'sen busun' diye istediğin kadar söyle. O insan kendini ne hissediyorsa odur” (NY, Eskişehir).

$\mathrm{Bu}$ yaklaşım, Barth’ın bireylerin kendilerini gruplar içinde tanımlama unsurlarına dair düşüncesini hatırlatmaktadır:

“İnsanlar sergiledikleri davranışlar açısından ne denli farklı olurlarsa olsunlar eğer kendilerini akraba bir topluluk olan B grubuna değil de A grubuna ait hissediyorlarsa bu tanımlamayı kimse engelleyemez. (...) İşte bizim üzerinde durmamız gereken konu, gruplar arasındaki objektif farklılıklar değil, bireylerin kendi kimliklerini tanımlarken kullandıkları unsurların neler olduğudur" (2001: 18).

Yapılan görüşmeler, çalışmanın öngördügü üzere Çerkeslerin “öteki” tanımlamalarında Kürtlerin önemli bir referans olduğunu göstermiştir. Buna ek olarak, pozitif ve negatif yorumların çeşitliliği ile homojen olmayan, farklı Çerkes etno-kültürel kimliklerin var olduğu; sürekli dönüşüm içerisinde olan bu Çerkes kimliklerinin siyasal, toplumsal, coğrafi, ekolojik ve ekonomik gibi çeşitli etmenlerle değiştiği (Barth, 2001) tespit edilmiştir.

Yapılan görüşmelerdeki görüşmeci profilinin çeşitliliği, hem jenerasyon farklılıklarını, hem de farklı siyasal, toplumsal vb. etmenler ile görüş ve tutum değişimlerini görmeye olanak sağlamıştır. Elde edilen veriler ile görülmüştür ki; Çerkes genç jenerasyonu halklar arası ilişkilere daha sorgulayıcı bakarken, orta yaş ve üstü katılımcılar (siyasal konumlanmasını sola daha yakın olarak nitelendirenler hariç) eski anlatılara daha bağlı görüşler belirtmektedir. Örneğin; genç kuşaktan görüşmeciler Türkler, Kürtler veya Ermeniler ile ilişkilerine tarihi perspektif ile sorgularken, orta yaş ve üstü katılımcılar Çerkeslerin Kurtuluş Savaşı’na 
önemli katkılarını örnek vermektedirler. Kolektif hafızada halen canlı bir yer tutan "Çerkes" Ethem Bey figürüne de bu çerçevede yeni anlamlar yüklenmekte ve sorgulanmaktadır. Buradan hareketle değişimi asla sonlanmayan kimliğin/kimliklerin, yeni jenerasyon tarafından daha sorgulayıcı bir biçimde dönüştürüleceği, kolektif hafızanın ve anlatıların üzerine daha çok düşünüleceği sonucuna ulaşmak mümkündür. Doğanay’ın belirttiği gibi, “Çerkesler 'damgalanmış’ Çerkez kimliklerini, ona yeni anlamlar yükleyerek ve geçmişi hatırlayarak, yeniden sahiplenmektedirler” (italik orijinal) (Doğanay, 2015: 365). ${ }^{26}$

${ }^{26}$ Çerkez ve Çerkes terimleri ile ilgili açıklama için, bkz. Besleney, 2016: 27 (italik orijinal). 


\section{SONUÇ}

Kimlik oluşum ve değişim süreçleri, tek bir boyuta indirgenerek incelenemeyecek kadar çeşitli ve girift boyutlar ve etmenler içermektedir. Çalışma, Türkiye'deki diasporaların kimlik oluşum, dönüşüm ve değişim süreçlerine bir örnek olarak Çerkes diasporasını incelemiş; veriler doğrultusunda Kürt halkı ve hareketine yapılan vurguları ele alarak, diasporik bir toplumun etno-kültürel kimliklerine dair ifadeleri ortaya koymuştur.

İlk olarak diaspora ve diasporik kimliklerin teorik çerçevesi Çerkesler özelinde tartışılmış; Çerkes diasporasının Türkiye' deki tarihi ve günümüzdeki varlığı, kurulan dernekler ve kapsamları açıklanmıştır. Daha sonraki bölümde elde edilen veriler ile, Çerkeslerin kendilerini birey ve topluluk olarak ifade ediş biçimleri, kimlik inşa ve süreçleri analiz edilmiştir.

Cumhuriyet'in ilk yıllarından itibaren kurulan Çerkes dernekleri, Türkiye' de Çerkeslerin kültürel ve politik faaliyetlerini devam ettirme mekânları ve bu çerçevede kimliğin önemli yeniden-üretilme araçları olmuştur. $\mathrm{Bu}$ doğrultuda Çerkes dernek temsilcileri ve kanaat önderleri ile yapılan derinlemesine mülakatlar doğrultusunda elde edilen veriler ile, Çerkeslerin kimliklerini tanımlama süreçleriyle kendilerini birey ve topluluk olarak ifade ediş biçimlerinde Kürtlere benzerlik ve farklılık temaları altında toplanabilecek çeşitli atıflarda bulunmuşlardır. Belirtilmelidir ki, benzerlik ve ötekilik temaları altında toplanan görüşmeler, kimi zaman birbiriyle örtüşebilmek ve birleşebilmektedir. Örneğin, Kürtlerin ana dil taleplerinin haklı bulunmasına rağmen iki hareket arasındaki amaç farklılıklarına dikkat çekilmiş, Çerkeslerin "Kürtler gibi bağımsızlık talebinde bulunmadığı” aynı kişi tarafından belirtilebilmiştir. Yine benzer şekilde, ana dil konusunda Kürt hareketinden etkilenildiği belirtilmesine rağmen, Çerkes hareketinin sadece bu etkileşim üzerinden değerlendirilmemesi gerektiği vurgulanabilmiştir. Bu örnekler, farklı Çerkes kimlikleri olduğu gibi, kimliklerin iç içe geçebileceğini ve farklı yaklaşımların da kişinin kimlik oluşumu içinde barınabileceğini göstermektedir. 
Buradan yola çıkarak, Çerkeslerin Kürt halkı ve hareketi örnekleri ile, diasporaların kendilerini tanımlama ve ifade ediş biçimlerinde "ötekinin" farklı anlamlar atfedilerek kullanılabileceği, bu atıfların çeşitli değişkenler doğrultusunda farkl1lık gösterebileceği görülmüştür (Barth, 2001). Öngörüldüğü üzere, diasporik bilince sahip genç Çerkes kuşağının, Kürt hareketinin siyasal ve sosyal kazanımlarından etkilenildiği vurgusuyla daha pozitif referanslar verildiği görülmüştür.

Çalışma, Türkiye'de bir diaspora halkının varlığını ifade ediş biçimlerindeki farklılıkları görmek açısından örnek oluşturmaya çalışmıştır. Çalışmanın sadece dernek yöneticilerinin ve kanaat önderlerinin görüşmeleriyle oluşturulduğu düşünülecek olursa, köylerde ve şehirlerde Çerkes halkı ile yapılacak görüşmeler, eksik yanları ortaya koymak açısından faydalı olacaktır. İleriki çalışmalar, benzer atıfların dernek yöneticileri ve kanaat önderleri üzerinden incelenmesiyle birlikte, köylerde ve şehirlerde yaşayan Çerkes halkının referansları ile de güçlendirilebilir. 


\section{SUMMARY}

Circassians have various cultural, political and social aspects which are significant to examine in detail. From this point of view, this study had examined a part of Circassian diaspora's identity construction, conversion and alteration processes in Turkey, by analyzing the examples of Kurdish references. These references had gathered from the interviews, which are conducted with Circassian association administratives and opinion leaders. The data shows us that Circassians had expressed themselves around two main pattern, which are highlighting differences and similarities with Kurdish people. Although the indicated references cover other people too, this study had focused on the most emphasised one.

Identity construction proceeds through the questions of "who am I?" and "who are we?". Thus, it can be specified that identity has two main dimensions, which cover a personel one and a collective one. Collective memory, history and shared/transferred moments are significant for collective/cultural memory and collective identity. In terms of Circassian diaspora in Turkey, associations have always been a significant transfer places for generations. The adventure that started in 1908 has still proceed for gaining an "ethnic minority" status, improving relationships with Caucasian republics, and generating legal circumstances in Caucasus.

Despite the formed common/collective memory, there are various thoughts and attitudes towards a great deal of subject, like every community. This study has also highlighted the differences among generations in the community with various socio-economic backgrounds, and attracted attention to several references. 


\section{KAYNAKÇA}

Adorno, T. W., Frenkel-Brunswik, E., Levinson, D. J., ve Sanford, R. N. (1950). The Authoritarian Personality. New York: Harper \& Brothers.

Akdeniz Göker, E. (2018). “Nereye Aitiz?” Diasporik Kimlik ve Türk Vatandaşlığı Kıskacında Çerkes Kimliği. AURUM Sosyal Bilimler Dergisi, 3 (1), 91-105.

Akgönül, S. (2009). Towards Minority Policies Beyond Reciprocity? The EU, Greece and Turkey. Othon Anastasakis, K. Nicolaidis ve K. Öktem (Eds.), In the Long Shadow of Europe: Greeks and Turks in the Era of Postnationalism içinde (s.191-217). Boston: Martinus Nijhoff.

Arslan, T. D. (2013). İstanbul'da Çerkes Kimliği. (Yayınlanmamış yüksek lisans tezi, Yeditepe Üniversitesi). İstanbul, Türkiye.

Assmann, J., Czaplicka, J. (1995). Collective Memory and Cultural Identity. Cultural History/Cultural Studies, 65, 125-133.

Assmann, J. (2001). Kültürel Bellek: Eski Yüksek Kültürlerde Yazı, Hatırlama ve Politik Kimlik. İstanbul: Ayrınt1.

Barth, F. (2001). Etnik Gruplar ve Sinırlart. Ayhan Kaya ve Seda Gürkan (Çev.). İstanbul: Bağlam Yayınc1lı.

Besleney, Z. A. (2009). An Overview of Circassian Studies Literature. Ergün Özgür (Ed.), The North Caucasus: Histories, Diasporas and Current Challenges içinde (s. 74-90). Ankara: Kaf-Dav Yayınları.

Besleney, Z. A. (2016). Türkiye’de Çerkes Diasporasının Siyasi Tarihi. İstanbul: İstanbul Bilgi Üniversitesi Yayınlar1.

Brubaker, R. ve Cooper, F. (2000). Beyond Identity. Theory and Society, 29, 1-47.

Brubaker, R. (2005). The 'Diaspora' Diaspora. Ethnic and Racial Studies, 28 (1), 1-19.

Chochiev, G. (2007). On the History of the North Caucasian Diaspora in Turkey. Iran \& the Caucasus, 11 (2), 213-226.

Clifford, J. (1994). Diasporas. Cultural Anthropology, 9 (3), 302-338. 
Cohen, R. (2008). Global Diasporas: An Introduction. London and New York: Routledge.

Çelikpala, M. (2005). Türkiye'de Kafkas Diyasporası ve Türk Dış Politikası'na Etkileri, Uluslararası İlişkiler, 2 (5), 71-108.

Dixon, J. C., Ergin, M. (2010). Explaining Anti-Kurdish Beliefs in Turkey: Group Competition, Identity, and Globalization. Social Science Quarterly, 91 (5), 1329-1348.

Doğan, S. N. (2009). Formations of Diaspora Nationalism: The Case of Circassians in Turkey. (Yayınlanmamış doktora tezi, Sabancı Üniversitesi). İstanbul, Türkiye.

Doğanay, G. (2015). Hatıralarla Kurulan bir Toplumsal Kimlik: 21 Mayıs 1864 Sürgünü ve Türkiyeli Çerkesler. Journal of Turkish Studies, 10 (10), 361-380.

Erciyes, J. C. (2008). Adyge-Abkhaz Returnees in the Ancestral Homeland, Diaspora, 17 (3), 340-361.

Erciyes, J. C. (2014). 21. Yüzyılda Kafkasya'ya Geri Göç: Adığe-Abhaz Diasporası ve "Dönüş”. Sevda Alankuş ve E. Oktay Ar1 (Eds.), Geçmişten Geleceğe Çerkesler: Kimlik, Kültür ve Siyaset içinde (s. 435-446). Ankara: Kafdav Yayınları.

Grassi, F. L. (2017). Yeni Bir Vatan: Çerkeslerin Osmanlı Imparatorluğu’na Zorunlu Göçü (1864). İstanbul: Tarihçi Kitabevi.

Hacısalihoğlu, M. (2013). 1864 Kafkas Tehciri: Kafkasya'da Rus Kolonizasyonu, Savaş ve Sürgün. İstanbul: Yıldız Teknik Üniversitesi Balkan ve Karadeniz Araştırmaları Merkezi.

Hall, S. (1994). Cultural Identity and Diaspora. Patrick Williams ve L.Chrismat1 (Eds.), Colonial Discourse and Post-Colonial Theory içinde (s.222-237). New York: Columbia University Press.

Hansen, L. F. (2012). Renewed Circassian Mobilization in the North Caucasus 20-years After the Fall of the Soviet Union. Journal on Ethnopolitics and Minority Issues in Europe, 11 (2), 103-135.

Karpat, K. (2017). Osmanlı'da Milliyetçiliğin Toplumsal Temelleri. İstanbul: Timaş Yayınları.

Kaya, A. (2001). Çevirmenin Sunuşu. Fredrik Barth (Ed.), Etnik Gruplar ve Sınırları içinde (s.7-8). İstanbul: Bağlam Yayıncılık. 
Kaya, A. (2005). Circassian Diaspora in Turkey: Stereotypes, Prejudices and Ethnic Relations. Nedret Kuran-Burçoğlu ve S. G. Miller (Eds.), Representations of the Others in the Meditarranean World and Their Impact on the Region içinde (s. 217-240). İstanbul: The ISIS Press.

Kaya, A. (2011). Türkiye'de Çerkesler: Diasporada Geleneğin Yeniden İcadı. İstanbul: İstanbul Bilgi Üniversitesi Yayınlar1.

Kaya, A. (2012). Çerkes Diasporası ve Ulusaşııı Alanın Ortaya Çıkardığı Yeni İhtiyaçlar. KAFFED Ortak Ak1l Toplantıs1 Sunumu, Bolu Koru Otel, Bolu. Erişim adresi: http://www.kaffed.org/bilgibelge/diaspora/item/820-\%C3\%A7erkes-diasporas\%C4\%B1-ve-

ulusa\%C5\%9F\%C4\%B1r\%C4\%B1-alan\%C4\%B1n-ortaya-

$\% \mathrm{C} 3 \% \mathrm{~A} 7 \% \mathrm{C} 4 \% \mathrm{~B} 1 \mathrm{kard} \% \mathrm{C} 4 \% \mathrm{~B} 1 \% \mathrm{C} 4 \% 9 \mathrm{~F} \% \mathrm{C} 4 \% \mathrm{~B} 1-$ yeni-ihtiya\%C3\%A7lar.html

Kirişçi, K. (2000). Disaggregating Turkish Citizenship and Immigration Practices. Middle Eastern Studies, $36(3), 1-22$.

Oran, B. (2004). Türkiye'de Azınlıklar: Kavramlar, Teori, Lozan, İç Mevzuat, İçtihat, Uygulama. İstanbul: İletişim Yayınları.

Özgür, E. (2011). The North Caucasian and Abkhazian Diasporas: Their Lobbying Activities in Turkey. Karina Vamling (Ed.), Caucasus Studies: Migration, Society and Language içinde (s. 80-88). Malmö: Malmö University.

Özgür, E. (2013). Türkiye'deki Kuzey Kafkas Diaspora Kurumları ve Lobi Faaliyetleri. Mehmet Hacısalihoğlu (Ed.), 1864 Kafkas Tehciri: Kafkasya'da Rus Kolonizasyonu, Savaş ve Sürgün içinde (s. 551-592). İstanbul: Yıldız Teknik Üniversitesi Balkan ve Karadeniz Araştırmaları Merkezi.

Özyürek, E. (2001). Hatırladıkları ve Unuttuklarıyla Türkiye’nin Toplumsal Hafizası. İstanbul: İletişim Yayınlar1.

Papşu, M. (2006). Çerkes-Adığe Yazısının Tarihçesi. Nart Dergisi, 51, 1-6. Erişim adresi: https://www.academia.edu/2762087/\%C3\%87erkesAd\%C4\%B1\%C4\%9Fe_Yaz\%C4\%B1s\%C4\%B1n\%C4\%B1n_Tarih\%C3\%A7esi

Richmond, W. (2013). The Circassian Genocide (Genocide, Political Violence, Human Rights). New Brunswick: Rutgers University Press. 
Safran, W. (1991). Diasporas in Modern Societies: Myths of Homeland and Return. Diaspora, 1 (1), 8399.

Sears, D. O. (1988). Symbolic Racism. Phyllis A. Katz ve D. A. Taylor (Eds.), Eliminating Racism içinde (s. 53-84). New York, NY: Plenum Press.

Shami, S. (1995). Disjuncture in Ethnicity: Negotiating Circassian Identity in Jordan, Turkey and the Caucasus. New Perspectives on Turkey, 12, 79-95.

Shenfield, S. D. (1999). The Circassians: A Forgotten Genocide. Mark Levene ve R. Penny (Eds.), The Massacre in History içinde (s. 149-162). New York, NY: Berghahn.

Sunata, U. (2015). Diasporanın Sosyokültürel Hafızası Olarak Çerkes Köyü. Sosyokültürel Yönleriyle Çerkes Toplumu içinde (s. 9-48). Ankara: Kaf-dav Yayınları.

Taymaz, E. (2001). Kuzey Kafkas Dernekleri. Stefanos Yerasimos (Ed.), Türkiye'de Sivil Toplumu ve Milliyetçilik içinde (s.451 460). İstanbul: İletişim Yayınları.

Toksabay, B. (2005). Conflict Over Language Rights: The Case of Kurds and Circassians in Turkey. (Yayınlanmamış yüksek lisans tezi, Sabancı Üniversitesi). İstanbul, Türkiye.

Toumarkine, A. (2001). Kafkas ve Balkan Göçmen Dernekleri: Sivil Toplum ve Milliyetçilik. Stefanos Yerasimos (Ed.), Türkiye'de Sivil Toplum ve Milliyetçilik içinde (s.425-450). İstanbul: İletişim Yayınları.

Tölölyan, K. (1996). Rethinking Diaspora(s): Stateless Power in the Transnational Moment, Diaspora, 5 (1), 3-36.

Uyan Semerci, P., Erdoğan, E., Sandal Önal, E. (2017). “Biz”liğin Aynasından Yanstyanlar. İstanbul: İstanbul Bilgi Üniversitesi Yayınları.

Vertovec, S. (1997). Three Meanings of "Diaspora”, Exemplified among South Asian Religions, Diaspora, $6(3), 277-299$.

Wakizaka, K. (2012). Türkiye'deki Gürcü ve Çerkes Diasporasının Gözüyle Abhazya Meselesi ve Kimlik Sorunu. (Yayınlanmamış yüksek lisans tezi, Yıldız Teknik Üniversitesi). İstanbul, Türkiye. 
Ek 1: Kanaat Önderleri ile Yapılan Yüz Yüze Görüşme Sayıları, İllere Göre

\begin{tabular}{|l|c|}
\hline İl & Görüşme sayısı \\
\hline Samsun & 5 \\
\hline Çorum & 3 \\
\hline Tokat & 4 \\
\hline Kayseri & 3 \\
\hline Kahramanmaraş & 4 \\
\hline Adana & 4 \\
\hline Osmaniye & 2 \\
\hline Eskişehir & 1 \\
\hline Balıkesir & 1 \\
\hline Toplam & $\mathbf{2 7}$ \\
\hline
\end{tabular}

